\title{
Preoperative Endovascular Embolization of Glomus Jugulare Tumors: A Retrospective Case Series of 22 Embolizations in 20 Patients and Literature Review
}

\section{Embolização endovascular pré-operatória de tumores de glômus jugular: Uma série de casos retrospectiva de 22 embolizações em 20 pacientes e revisão da literatura}

\author{
Matheus Kahakura Franco Pedro ${ }^{1,2(1)}$ André Giacomelli Leal 2,3(1) Ricardo Ramina 3 ,40 \\ Murilo Sousa de Meneses,30
}

${ }^{1}$ Department of Neurology, Neurological Institute of Curitiba, Curitiba, PR, Brazil

2 Department of Endovascular Neurosurgery and Interventional Neuroradiology, Neurological Institute of Curitiba, Curitiba, PR, Brazil

${ }^{3}$ Department of Vascular Neurosurgery, Neurological Institute of Curitiba, Curitiba, PR, Brazil

${ }^{4}$ Department of Skull Base Surgery, Neurological Institute of Curitiba, Curitiba, PR, Brazil

\begin{abstract}
Address for correspondence Matheus Kahakura Franco Pedro, MD, Departments of Neurology, Endovascular Neurosurgery and Interventional Neuroradiology, Instituto de Neurologia de Curitiba, Jeremias Maciel Perretto, 300, Curitiba, Paraná, 81210-310, Brazil (e-mail: matheuskfpedro@hotmail.com).
\end{abstract}

Arq Bras Neurocir 2022;41(1):e26-e34.

\begin{abstract}
Objective Glomus jugulare tumors, or tympanojugular paragangliomas, are rare, highly vascularized skull base tumors originated from paraganglion cells of the neural crest. With nonabsorbable embolic agents, embolization combined with surgery has become the norm. The authors assess the profile and outcomes of patients submitted to preoperative embolization in a Brazilian tertiary care hospital.

Methods The present study is a single-center, retrospective analysis; between January 2008 and December 2019, 22 embolizations were performed in 20 patients in a preoperative character, and their medical records were analyzed for the present case series.

Keywords

- endovascular procedures

- glomus jugulare

- therapeutic embolization

Results Hearing loss was the most common symptom, present in $50 \%$ of the patients, while $40 \%$ had tinnitus, $30 \%$ had dysphagia, $25 \%$ had facial paralysis, $20 \%$ had hoarseness, and $10 \%$ had diplopia. In 7 out of 22 embolization procedures (31\%) more than a single embolic agent was used; Gelfoam (Pfizer, New York, NY, USA) was used in 18 procedures (81\%), in 12 of which as the single agent, followed by Embosphere (Merit Medical, South Jordan, UT, USA) (31\%), Onyx (Medtronic, Minneapolis, MN, USA) (9\%), and polyvynil

received

November 9, 2020

accepted

June 16, 2021

published online

December 17, 2021

DOI https://doi.org/ $10.1055 / \mathrm{s}-0041-1739270$ ISSN 0103-5355.

\footnotetext{
(c) 2021. Sociedade Brasileira de Neurocirurgia. All rights reserved. This is an open access article published by Thieme under the terms of the Creative Commons Attribution-NonDerivative-NonCommercial-License, appropriate credit. Contents may not be used for commercial purposes, or adapted, remixed, transformed or built upon. (https://creativecommons.org/ licenses/by-nc-nd/4.0/)

Thieme Revinter Publicações Ltda., Rua do Matoso 170, Rio de Janeiro, RJ, CEP 20270-135, Brazil
} permitting copying and reproduction so long as the original work is given
\end{abstract}




\section{Resumo}

\author{
Palavras-chave \\ - procedimentos \\ endovasculares \\ - gomo jugular \\ - embolização \\ terapêutica
}

alcohol (PVA) and Bead Block (Boston Scientific, Marlborough, MA, USA) in 4,5\% each. The most common vessel involved was the ascending pharyngeal artery, involved in $90 \%$ of the patients, followed by the posterior auricular artery in $15 \%$, the internal maxillary artery or the occipital artery in $10 \%$ each, and the superficial temporal or the lingual arteries, with $6 \%$ each. Only one patient had involvement of the internal carotid artery. No complications from embolization were recorded.

Conclusions Preoperative embolization of glomus tumors is safe and reduces surgical time and complications, due to the decrease in size and bleeding.

Objetivo Tumores de glômus jugular, ou paragangliomas timpanojugulares, são tumores de base de crânio raros, altamente vascularizados, originados das células paragangliônicas da crista neural. Com agentes embólicos não-absorvíveis, embolização combinada com cirurgia se tornou a norma. Os autores avaliam os perfis e desfechos de pacientes submetidos a embolização pré-operatória em um hospital terciário brasileiro.

Métodos O presente estudo é uma análise retrospectiva realizada em centro único; entre janeiro de 2008 e dezembro de 2019, 22 embolizações foram realizadas em 20 pacientes em caráter pré-operatório. Seus registros médicos foram analisados para a presente série de casos.

Resultados Hipoacusia foi o sintoma mais comum, presente em $50 \%$ dos pacientes, enquanto $40 \%$ tinham tinnitus, $30 \%$ tinham disfagia, $25 \%$ tinham paralisia facial, $20 \%$ tinham rouquidão e 10\% tinham diplopia. Em 7 das 22 embolizações (31\%), mais de 1 agente embólico foi utilizado; Gelfoam (Pfizer, Nova York, NY, EUA) foi usado em 18 procedimentos (81\%), em 12 dos quais como agente único, seguido de Embosphere (Merit Medical, South Jordan, UT, EUA) (31\%), Onyx (Medtronic, Minneapolis, MN, USA) (9\%), e polyvynil alcohol (PVA) e Bead Block (Boston Scientific, Marlborough, MA, EUA) (4,5\% cada). Os vasos mais comumente acometidos foram a artéria faríngea ascendente (90\% dos pacientes), seguida da artéria auricular posterior (15\%), a artéria maxilar interna e a artéria occipital ( $10 \%$ cada) e as artérias temporal superficial e lingual ( $6 \%$ cada). Apenas um paciente teve acometimento da artéria carótida interna. Não houve complicação secundária a embolização.

Conclusão Embolização pré-operatória de glômus jugular é segura e reduz tempo e complicações cirúrgicas, pela redução em tamanho e sangramento.

\section{Introduction}

Glomus jugulare tumors, more recently described as tympanojugular paragangliomas, are rare, highly vascularized though slow-growing skull base tumors that originate from paraganglion cells of the neural crest. ${ }^{1}$ Even though their histological substrate is benign, they often present as aggressive lesions, invading the temporal bone, the upper neck, the middle ear, and the jugular foramen itself. ${ }^{2}$ The approach for these lesions remains controversial: while radiosurgery, radiotherapy, and gamma knife radiosurgery as primary treatments showed high rates of growth afterwards, they had low morbidity ${ }^{3-7}$; meanwhile, neurosurgeons are often faced with challenges due to the rich vascularization of the lesions as well as to the intimate relationship with neural and vascular structures. ${ }^{1,2,8,9}$ To minimize the risks for the patient and ensure total resection, a combined approach involving neurosurgeon, interventional radiologist, and ear, nose, and throat (ENT) surgeon is ideal. ${ }^{10}$ After the introduction of modern, nonabsorbable embolic agents, embolization combined with surgery after at least 2 days has become the norm. Since 2008 , the authors have treated 20 patients with this combined approach; in the present series, we present the results of a retrospective analysis of this group.

\section{Patients and Methods}

Between January 2008 and December 2019, 22 paraganglioma embolizations were performed in 20 patients in a preoperative character in the Neurological Institute of Curitiba (INC, in the Portuguese acronym), a tertiary reference center in Southern Brazil. There were 11 women (55\%) and 9 men (45\%), with a mean age of $51.25 \pm 16.3$ years old (range: 23 to 87 years old). A total of $50 \%$ of the lesions were on the 
right side. All patients with glomus jugulare who presented to our service underwent both embolization and surgery afterwards. Every single patient is still alive and in regular follow-up with the team.

The present study is a retrospective analysis of a series of cases treated by the same team (neurosurgeons and interventional neuroradiologists); the procedures were performed in either a Siemens AXIOM system (Siemens, Munich, Germany) (before 2013) or a Philips Allura Xper FD20 system (Philips, Amsterdam, Netherlands) (since 2013). Given the retrospective nature of the present case series, institutional approval was obtained from the Committee of Ethics in Research of our institution (approval protocol 4.211.396) but the need to obtain a consent form was waived.

As previously reported by the group, embolization of glomus jugulare tumors was performed through super selective catheterization of feeder arteries between 3 to 5 days prior the surgical procedure; feeders from the external carotid artery (ECA [ascending pharyngeal, internal, maxillary, and occipital arteries, for instance]) and internal carotid artery (ICA [through carotid tympanic branches]) were embolized with gelatin foam (Gelfoam; Pfizer, New York, NY, USA), polyvinyl alcohol foam, or polyvynil alcohol (PVA) (Ivalon; Nycomed, Paris, France) particles, embolic spheres (Embosphere; Merit Medical, South Jordan, UT, USA), Bead Block (Boston Scientific, Marlborough, MA, EUA), and ethylene-vinyl alcohol copolymer, or EVOH (Onyx; Medtronic, Minneapolis, MN); the choice of the materials was subject to medical indication as well as to authorization by the health insurance provider of each patient. The aim of the treatment was radical and complete tumor removal in one surgical procedure with preservation of the cranial nerves. ${ }^{10}$

\section{Results}

Of the 20 patients who presented to our department for evaluation, 11 (55\%) had already been submitted to previous neurosurgical procedures (-Table 1). Hearing loss was the most common symptom, present in 10 patients (50\%), while 8 (40\%) had tinnitus, $6(30 \%)$ had dysphagia, 5 (25\%) had facial paralysis (classified as House-Brackmann [HB] 2 in 2 patients, HB 3 in 1 patient, and HB 4 in 2 patients), 4 (20\%) had hoarseness, and 2 (10\%) had diplopia. While 11 patients (55\%) reported no previous medical condition, hypertension was found in 6 patients (30\%), diabetes and dyslipidemia were found in 2 patients each (10\%), clinically-diagnosed generalized anxiety, tabagism, and atrial fibrillation were reported in 1 patient each (5\%).

In 7 out of 22 embolization procedures (31\%) more than a single embolic agent was used; Gelfoam was used in 18 procedures ( $81 \%$ ), in 12 of which as the single agent, followed by Embosphere in 7 procedures (31\%), Onyx in 2 procedures (9\%), and PVA and Bead Block in 1 each $(4,5 \%)$.

Concerning the arterial feeder, 5 patients (25\%) had multiple arteries involved; the most common vessel was the ascending pharyngeal branch of the external carotid artery, involved in 18 patients (90\%), followed by the posterior auricular artery in 3 cases (15\%), the internal maxillary artery and the occipital artery in 2 cases each (10\%), and the superficial temporal and the lingual arteries, with 1 case each (5\%). Only 1 patient (5\%) had involvement of the ICA; she was submitted to 3 procedures, and after the $1^{\text {st }}$ the ICA supply was terminated; later, she underwent direct lesion injection of Onyx as well, our sole procedure with direct percutaneous injection of any agent.

The embolization was deemed total by the interventionist in 13 procedures (59\%), partial in 4 procedures (18\%), and was not reported in the remaining 5 (-Table 2 ). No complications were reported after the embolizations. Surgical resection, on the other hand, was considered total in 12 (60\%) of the patients and partial in $8(40 \%)$. Further microsurgery was indicated in 2 patients (10\%), and stereotactic radiosurgery (Leksell Gamma Knife Perfexion; Stockholm, Sweden), in 4 patients (20\%).

Postoperative symptoms included dysphagia in 4 patients (20\%), worsening of hearing loss in 3 patients (15\%), cerebrospinal fluid (CSF) leak in 2 patients (10\%), and worsening of facial paralysis or surgical site granuloma in 1 patient each (5\%), with tracheal laceration, necrosis of skin graft, and bone exposition in a specific patient. All patients are alive to this date; -Figs. 1 and $\mathbf{2}$ provide clinical examples.

\section{Discussion}

While rare, slow-growing and histologically benign, glomus jugulare tumors are considered aggressive lesions; invasion of temporal bone, of the middle ear, of the neck, and of vascular structures is common. Their most defining aspect is their hypervascularization, which directly influences both imaging and treatment. ${ }^{1,2}$

Concerning imaging features, preoperative digital subtraction angiogram (DSA) is still a vital component of both a correct diagnosis of glomus jugulare tumors, allowing for differential diagnosis with schwannomas, for instance, as well as of the dynamic evaluation of the lesion, identifying a hypervascular mass with rapid arterial blushing, the feeder arteries, which are often hypertrophied, as well as a possible involvement of the internal carotid artery, and venous drainage, often enlarged, possible compression or enlargement of the jugular vein, not to mention size and possible occlusion of the jugular bulb or involvement of the middle ear. ${ }^{10,11}$ Magnetic resonance imaging (MRI) with gadolinium injection displays the characteristics, size, and extension of the lesion, as well as its relationship with neighboring structures. $^{12,13}$ Glomus jugulare tumors appear as well vascularized lesions, with heterogeneous gadolinium enhancement on T1WI in the typical "salt and pepper" pattern, representing dark vascular flow voids and intense contrast enhancement; on T2WI, the tumors are heterogeneous with dark flow voids. ${ }^{11,14}$ Computed tomography (CT) may be useful for analysis of neighboring bone structures and possible invasion ${ }^{11}$; a noncontrast CT typically shows a poorly defined soft tissue mass along with a destructive bony aspect within the jugular foramen. ${ }^{12,15,16}$

Concerning the treatment rationale, tumor embolization is a centenary idea; Dawbarn first described in 1904 a 
Table 1 Baseline characteristics of the patients

\begin{tabular}{|c|c|c|c|c|c|c|c|}
\hline Patient & $\begin{array}{l}\text { Age } \\
\text { (years old) }\end{array}$ & Sex & $\begin{array}{l}\text { Previous } \\
\text { diseases }\end{array}$ & Clinical features & $\begin{array}{l}\text { Lesion } \\
\text { laterality }\end{array}$ & Arterial supply & $\begin{array}{l}\text { Previous } \\
\text { surgery }\end{array}$ \\
\hline 1 & 87 & Female & $\begin{array}{l}\text { Arterial } \\
\text { hypertension, } \\
\text { dyslipidemia }\end{array}$ & $\begin{array}{l}\text { Hearing loss, vertigo, } \\
\text { facial paralysis } \\
\text { (House-Brackmann 3), } \\
\text { hoarseness, cough, } \\
\text { dysphagia }\end{array}$ & Right & $\begin{array}{l}\text { Ascending pharyngeal } \\
\text { artery, posterior } \\
\text { auricular artery }\end{array}$ & Yes \\
\hline 2 & 49 & Male & $\begin{array}{l}\text { Arterial } \\
\text { hypertension, } \\
\text { tabagism }\end{array}$ & Hearing loss, dysphagia & Right & $\begin{array}{l}\text { Posterior auricular } \\
\text { artery }\end{array}$ & Yes \\
\hline 3 & 63 & Female & Not reported & Not reported & Left & $\begin{array}{l}\text { Ascending pharyngeal } \\
\text { artery, occipital artery }\end{array}$ & $\begin{array}{l}\text { Not } \\
\text { reported }\end{array}$ \\
\hline 4 & 37 & Male & Not reported & Not reported & Right & $\begin{array}{l}\text { Superficial temporal } \\
\text { artery }\end{array}$ & $\begin{array}{l}\text { Not } \\
\text { reported }\end{array}$ \\
\hline 5 & 65 & Female & $\begin{array}{l}\text { Arterial } \\
\text { hypertension }\end{array}$ & Tinnitus & Right & $\begin{array}{l}\text { Ascending pharyngeal } \\
\text { artery }\end{array}$ & No \\
\hline 6 & 51 & Female & None & Hoarseness & Left & $\begin{array}{l}\text { Ascending pharyngeal } \\
\text { artery }\end{array}$ & No \\
\hline 7 & 70 & Female & None & $\begin{array}{l}\text { Hearing loss, tinnitus, } \\
\text { facial paralysis } \\
\text { (House-Brackmann 2) }\end{array}$ & Right & $\begin{array}{l}\text { Ascending pharyngeal } \\
\text { artery }\end{array}$ & Yes \\
\hline 8 & 41 & Male & None & $\begin{array}{l}\text { Asymptomatic (incidental } \\
\text { finding) }\end{array}$ & Right & $\begin{array}{l}\text { Ascending pharyngeal } \\
\text { artery }\end{array}$ & Yes \\
\hline 9 & 60 & Female & None & Dysphagia, diplopia & Right & $\begin{array}{l}\text { Ascending pharyngeal } \\
\text { artery }\end{array}$ & Yes \\
\hline 10 & 32 & Female & None & Hearing loss, hoarseness & Left & $\begin{array}{l}\text { Ascending pharyngeal } \\
\text { artery }\end{array}$ & No \\
\hline 11 & 36 & Male & None & $\begin{array}{l}\text { Hearing loss, facial paralysis } \\
\text { (House-Brackmann 2), } \\
\text { diplopia }\end{array}$ & Left & $\begin{array}{l}\text { Ascending pharyngeal } \\
\text { artery }\end{array}$ & Yes \\
\hline 12 & 40 & Male & $\begin{array}{l}\text { Arterial } \\
\text { hypertension }\end{array}$ & Tinnitus & Right & $\begin{array}{l}\text { Ascending pharyngeal } \\
\text { artery }\end{array}$ & Yes \\
\hline 13 & 81 & Female & $\begin{array}{l}\text { Arterial } \\
\text { hypertension, } \\
\text { type } 2 \text { diabetes }\end{array}$ & $\begin{array}{l}\text { Facial paralysis } \\
\text { (House-Brackmann 4), } \\
\text { hearing loss }\end{array}$ & Left & $\begin{array}{l}\text { Ascending pharyngeal } \\
\text { artery, maxillary } \\
\text { artery }\end{array}$ & Yes \\
\hline 14 & 55 & Male & $\begin{array}{l}\text { Generalized } \\
\text { anxiety }\end{array}$ & Dysphagia, hoarseness & Left & $\begin{array}{l}\text { Ascending pharyngeal } \\
\text { artery }\end{array}$ & Yes \\
\hline 15 & 55 & Female & None & $\begin{array}{l}\text { Tinnitus, dysphagia, } \\
\text { facial paralysis } \\
\text { (House-Brackmann 4), } \\
\text { hearing loss, lesion } \\
\text { extrusion through external } \\
\text { acoustic meatus }\end{array}$ & Right & $\begin{array}{l}\text { Ascending pharyngeal } \\
\text { artery, maxillary } \\
\text { artery, internal carotid } \\
\text { artery }\end{array}$ & Yes \\
\hline 16 & 23 & Male & None & Hearing loss, tinnitus & Right & $\begin{array}{l}\text { Ascending pharyngeal } \\
\text { artery }\end{array}$ & No \\
\hline 17 & 44 & Male & None & Hearing loss & Left & $\begin{array}{l}\text { Ascending pharyngeal } \\
\text { artery, lingual artery }\end{array}$ & Yes \\
\hline 18 & 60 & Female & $\begin{array}{l}\text { Arterial } \\
\text { hypertension, } \\
\text { atrial fibrillation, } \\
\text { type } 2 \text { diabetes, } \\
\text { dyslipidemia, } \\
\text { interatrial } \\
\text { communication }\end{array}$ & $\begin{array}{l}\text { Tinnitus, auricular } \\
\text { discomfort }\end{array}$ & Left & $\begin{array}{l}\text { Ascending pharyngeal } \\
\text { artery, posterior } \\
\text { auricular artery }\end{array}$ & No \\
\hline 19 & 43 & Female & None & $\begin{array}{l}\text { Tinnitus, hearing loss, facial } \\
\text { paresthesia }\end{array}$ & Left & $\begin{array}{l}\text { Ascending pharyngeal } \\
\text { artery, occipital artery }\end{array}$ & No \\
\hline 20 & 33 & Male & None & Tinnitus, dysphagia & Left & $\begin{array}{l}\text { Ascending pharyngeal } \\
\text { artery }\end{array}$ & No \\
\hline
\end{tabular}


30 Preoperative Endovascular Embolization of Glomus Jugulare Tumors Pedro et al.

Table 2 Embolization and microsurgical characteristics of the patients

\begin{tabular}{|c|c|c|c|c|c|c|}
\hline Patient & Embolic agent & $\begin{array}{l}\text { Complete } \\
\text { embolization? }\end{array}$ & $\begin{array}{l}\text { Complications from } \\
\text { embolization }\end{array}$ & $\begin{array}{l}\text { Complications from } \\
\text { surgical resection }\end{array}$ & Outcome & $\begin{array}{l}\text { Necessity of } \\
\text { new surgical } \\
\text { approach }\end{array}$ \\
\hline 1 & Gelfoam & Yes & None & None & $\begin{array}{l}\text { Complete } \\
\text { resection }\end{array}$ & None \\
\hline 2 & PVA & Yes & None & Complete hearing loss & $\begin{array}{l}\text { Complete } \\
\text { resection }\end{array}$ & None \\
\hline 3 & $\begin{array}{l}\text { Embosphere and } \\
\text { Gelfoam }\end{array}$ & Yes & None & None & $\begin{array}{l}\text { Complete } \\
\text { resection }\end{array}$ & None \\
\hline 4 & Gelfoam & Yes & None & None & $\begin{array}{l}\text { Complete } \\
\text { resection }\end{array}$ & None \\
\hline 5 & $\begin{array}{l}\text { Embosphere and } \\
\text { Gelfoam }\end{array}$ & Yes & None & Local granuloma & $\begin{array}{l}\text { Incomplete } \\
\text { resection }\end{array}$ & Open surgery \\
\hline 6 & Embosphere & Yes & None & None & $\begin{array}{l}\text { Incomplete } \\
\text { resection }\end{array}$ & $\begin{array}{l}\text { Gamma Knife } \\
\text { radiosurgery }\end{array}$ \\
\hline 7 & $\begin{array}{l}\text { Embosphere and } \\
\text { Gelfoam }\end{array}$ & Not described & None & Not reported & $\begin{array}{l}\text { Complete } \\
\text { resection }\end{array}$ & None \\
\hline 8 & $\begin{array}{l}\text { Embosphere and } \\
\text { Gelfoam }\end{array}$ & Not described & None & None & $\begin{array}{l}\text { Incomplete } \\
\text { resection }\end{array}$ & Open surgery \\
\hline 9 & $\begin{array}{l}\text { Embosphere and } \\
\text { Gelfoam }\end{array}$ & Not described & None & $\begin{array}{l}\text { Cerebrospinal fluid } \\
\text { leak }\end{array}$ & $\begin{array}{l}\text { Incomplete } \\
\text { resection }\end{array}$ & $\begin{array}{l}\text { Gamma Knife } \\
\text { radiosurgery }\end{array}$ \\
\hline 10 & Gelfoam & Not described & None & None & $\begin{array}{l}\text { Complete } \\
\text { resection }\end{array}$ & None \\
\hline 11 & $\begin{array}{l}\text { Embosphere and } \\
\text { Gelfoam }\end{array}$ & Partial & None & None & $\begin{array}{l}\text { Complete } \\
\text { resection }\end{array}$ & None \\
\hline 12 & Gelfoam & Yes & None & None & $\begin{array}{l}\text { Complete } \\
\text { resection }\end{array}$ & None \\
\hline 13 & Gelfoam & Yes & None & $\begin{array}{l}\text { Worsening of } \\
\text { facial paralysis } \\
\text { (House-Brackmann 5) }\end{array}$ & $\begin{array}{l}\text { Incomplete } \\
\text { resection }\end{array}$ & $\begin{array}{l}\text { Gamma Knife } \\
\text { radiosurgery }\end{array}$ \\
\hline 14 & Gelfoam & Not described & None & $\begin{array}{l}\text { Worsening of } \\
\text { dysphagia }\end{array}$ & $\begin{array}{l}\text { Complete } \\
\text { resection }\end{array}$ & None \\
\hline \multirow[t]{3}{*}{15} & $\begin{array}{l}\text { Gelfoam - first } \\
\text { embolization }\end{array}$ & Partial & None & $\begin{array}{l}\text { Tracheal laceration, } \\
\text { necrosis of skin graft, } \\
\text { bone exposition }\end{array}$ & $\begin{array}{l}\text { Incomplete } \\
\text { resection }\end{array}$ & None \\
\hline & $\begin{array}{l}\text { Gelfoam - second } \\
\text { embolization }\end{array}$ & Partial & None & & & \\
\hline & $\begin{array}{l}\text { Onyx - third } \\
\text { embolization } \\
\text { (intralesional) }\end{array}$ & Partial & None & & & \\
\hline 16 & Gelfoam & Yes & None & $\begin{array}{l}\text { Cerebrospinal fluid } \\
\text { leak, worsening } \\
\text { of hearing loss, } \\
\text { dysphagia, and } \\
\text { tinnitus }\end{array}$ & $\begin{array}{l}\text { Incomplete } \\
\text { resection }\end{array}$ & $\begin{array}{l}\text { Gamma Knife } \\
\text { radiosurgery }\end{array}$ \\
\hline 17 & $\begin{array}{l}\text { Gelfoam, Onyx, } \\
\text { Bead Block }\end{array}$ & Yes & None & None & $\begin{array}{l}\text { Incomplete } \\
\text { resection }\end{array}$ & None \\
\hline 18 & Gelfoam & Yes & None & None & $\begin{array}{l}\text { Complete } \\
\text { resection }\end{array}$ & None \\
\hline 19 & Gelfoam & Yes & None & Dysphagia & $\begin{array}{l}\text { Complete } \\
\text { resection }\end{array}$ & None \\
\hline 20 & Gelfoam & Yes & None & $\begin{array}{l}\text { Worsening of } \\
\text { dysphagia }\end{array}$ & $\begin{array}{l}\text { Complete } \\
\text { resection }\end{array}$ & None \\
\hline
\end{tabular}

Abbreviation: PVA: polyvynil alcohol. 


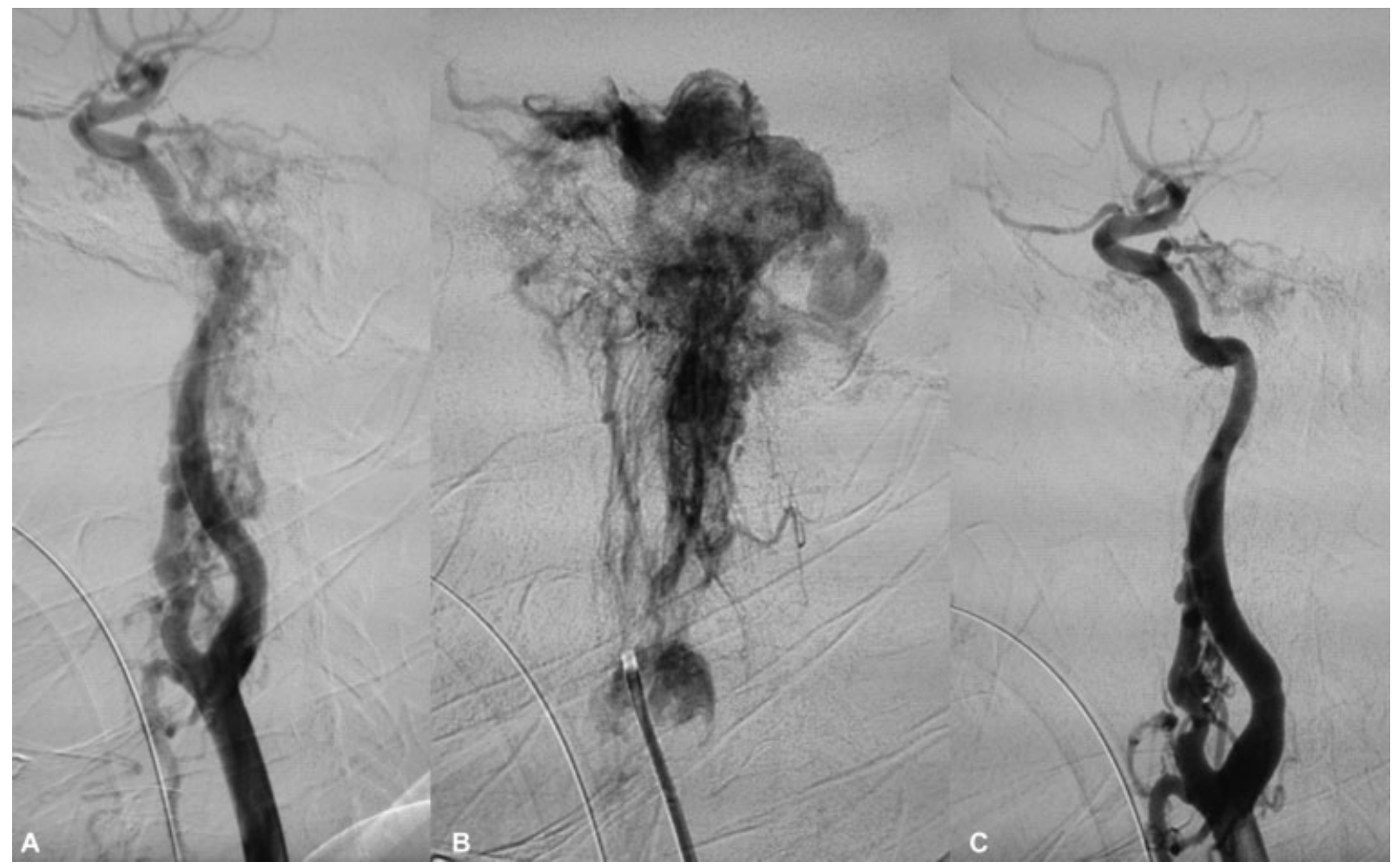

Fig. 1 A 36-year-old male who first presented with hypoacusia, with later development of HB 2 facial paralysis, had been previously operated without embolization. He had no known comorbidities. He was evaluated at our institution and was submitted to embolization of glomus jugulare tumor with Gelfoam and Embosphere by selective catheterization of the left ascending pharyngeal artery, which was shown by angiography to be the main feeder. The patient had no complications from the procedure and underwent surgery without complications as well, achieving complete resection and needing no further treatment. All images are lateral DSA acquisitions during embolization. A: early arterial phase of vast left side hypervascularized, invasive tumor fed by the ascending pharyngeal artery. B: late arterial phase after selective catheterization of the ascending pharyngeal artery. C: control early arterial acquisition showing significant decrease of the lesional blood supply.

"starvation plan" for facial sarcomas and carcinomas ${ }^{17}$; after surgical access, the ECA would be cannulized and liquid paraffin would be injected. In 1930, Brooks reported the use of autologous muscle to close a post-traumatic carotidcavernous fistula. ${ }^{18}$ Cerebral angiography, as we know it, also had a long history, since the days of Egas Moniz and his studies on surgically exposed cervical carotid arteries, ${ }^{19,20}$ passing through the technical advances of Seldinger in 1953, creator of the modern percutaneous arterial access, ${ }^{21}$ and Djindjian, who first described superselective catheterization of branches of the ECA. ${ }^{22}$

The first reported case of glomus jugulare tumor embolization was in 1973, by Hekster, ${ }^{23}$ with autologous muscle; the first uses of Gelfoam, Silastic (American Heyer Schulte, Goleta, CA, USA) spheres, and adhesives through ECA branches was published by Hilal in $1975 .{ }^{24}$ Since then, the use of the technique spread and allowed for experiences with different materials. The first use of PVA was in a carotid body tumor in 1980 , by Schick. ${ }^{25}$ Since then, the use of the technique spread and allowed for experiences with different materials. In 1994, George et al. documented the first direct, intralesional injection of n-butyl-cyanoacrylate (NBCA) in paragangliomas, ${ }^{26}$ followed by the description by Jacobs of combined arterial and venous preoperative embolization ${ }^{27}$; in our series, we had only one case of direct intralesional injection, and no case of combined arterial and venous approach.
Paragangliomas are often fed by branches of the ECA, especially the ascending pharyngeal artery, the occipital artery, and the posterior auricular artery; intracranial invading tissue may be supplied by the clival meningeal branches of the ICA and the meningeal branches of the vertebral artery. In case of intradural extension to the posterior fossa, both the posterior and the anterior inferior cerebellar arteries may be involved. ${ }^{1,28,29}$

It has been long known that embolization of glomus jugulare tumors are most successful when combined with other therapeutic modalities, due to high rates of revascularization, ${ }^{1,29-32}$ as well as the multitude of feeding arteries and pedicles originating from eloquent branches ${ }^{30,33}$; preoperative embolization is vital in decreasing blood loss during surgical resection, allowing for safer surgeries. ${ }^{29}$ It also may reduce surgical exposure time, spare a patient from thermocoagulation trauma, and prevent sinus-packing procedures. ${ }^{30}$

While generally safe, ${ }^{29}$ preoperative embolization is not risk-free. Low cranial nerve palsy, presumably due to embolic ischemia of the vasa nervorum or tumor embolic infarction with swelling and nerve compression, stroke, due to reflux or withdraw-induced embolism, or dramatic hypotension, after embolization of a large catecholamine-secreting tumor, have all been described, even if their incidence is extremely low. ${ }^{26,34-36}$ In our series, we had no complications arising from the embolization per se. 


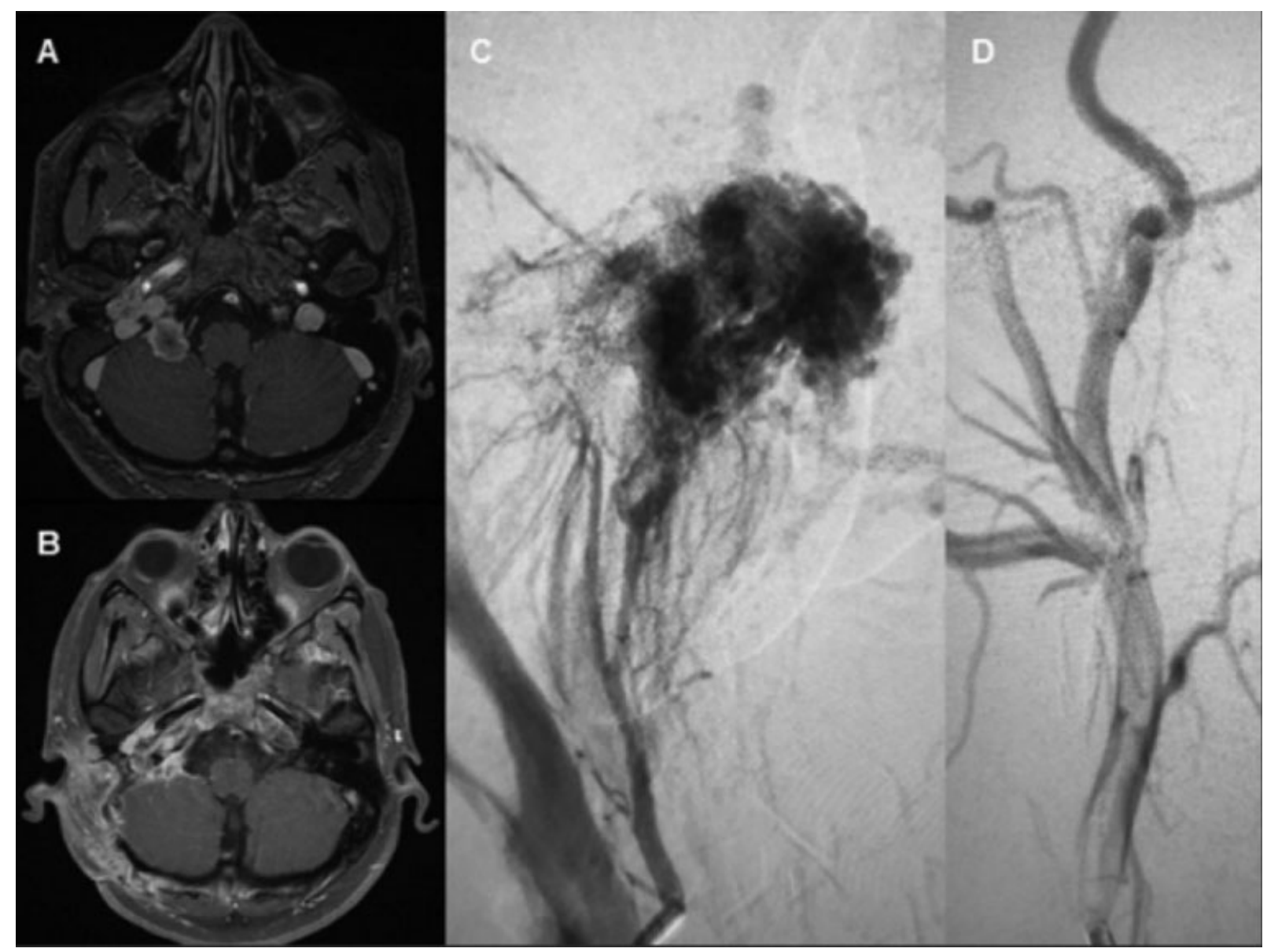

Fig. 2 A 21-year-old male complained of right side pulsatile tinnitus and hypoacusia for 10 months, as well as intermittent ipsilateral cervical pain, before admission to our hospital. ENT examinations elsewhere were without imaging, and he only performed CT and MRI examinations after our evaluation. Both revealed a large, invasive tumor in the jugulare foramen; DSA revealed the tumor was completely supplied by the ascending pharyngeal artery. The patient underwent a total embolization with Gelfoam and the tumor was resected in the same week, using a right craniocervical access. Afterwards, the patient developed CSF leak, later corrected. Due to extensive involvement of glossopharyngeal and accessory nerves, the patient underwent Gamma Knife radiosurgery ( $25 \mathrm{~Gy}, 50 \%$ isodose) as adjuvant treatment. A and B: axial, postgadolinium injection T1W1 images showing right side hypervascularized lesion in the foramen jugulare, before and after surgery. C: lateral DSA acquisition after selective catheterization of the ascending pharyngeal artery showing the hypervascularized glomus jugulare. D: control lateral DSA acquisition with catheterization of the external carotid artery after embolization with Gelfoam.

Many techniques have been described thus far, ranging from transarterial embolization with PVA particles to direct, percutaneous embolization with NBCA or Onyx. ${ }^{30,36,37}$ It must be noted that not only does embolization provide better surgical outcomes but it also has positive impact in clinical manifestations such as tinnitus and vertigo. ${ }^{38}$ Even though use of embolization as sole treatment is not advised, it may provide radiological stabilization as well. . $^{39,40}$

The following surgery should ideally be performed on the $3^{\text {rd }}$ and on the $14^{\text {th }}$ day after embolization, giving time for decrease of the edema generated by the embolization but before possible vessel reopening and recruiting of other arterial feeders. It is worth noting that paragangliomas may be highly compartmentalized, with independent segments fed by different branches. In our series, total embolization was achieved in $47 \%$ of the cases.

Embolization is typically done through one or more of three techniques: transarterially, injecting the embolic agent through superselective catheterization; direct percutaneous intratumoral puncture, which may close arterial supply, capillary bed, and venous drainage, but is harder to adequately gauge; and a transvenous injection, including occlusion of the inferior petrous sinus. ${ }^{26,27,30}$

Agents available for arterial use include autologous muscle, NBCA glue, Ethylene Vynil Alcohol Copolymer (EVOH) (Medtronic, Minneapolis, MN, USA), ethanol, hydrogel, microcoils, microspheres, Gelfoam gelatin sponge, PVA, and microfibrilar collagen, which may be used independently or in association with one another. Both permanent ICA ballooning and carotid stenting may be warranted in selected cases, including cases in which the tumor is extensively supplied by the ICA. ${ }^{29,41,42}$ Factors that may influence the choice of embolic agent include, but are not limited to, the experience of the neurointerventionalist with each substance, the time lapse until the surgery, and the possibility of total occlusion. For instance, while the use of microspheres may allow for deeper penetration within the lesion and later open surgery, less experienced 
neurointerventionalists may underestimate the diffusion of the substance, especially those with smaller diameters, and inadvertently generate distal venous embolization. In our case, we preferred the larger Gelfoam due to standard procedure of scheduling surgeries in the following days after the embolization and better prevention of venous emboli. This reasoning finds exception when concerning direct injection, either with Onyx, Precipitating Hydrophobic Injectable Liquid (PHIL) (Microvention, Tustin, CA, USA) or NCBA, ${ }^{26,43}$ in which preoccupations such as incomplete embolization are also due to care to not inject into the arterial circulation.

We note that our series is one of the largest to date, with few having more patients when specifically concerning glomus jugulare lesions and not all skull base tumors. However, our case series is not without limitations, which include the single-center, retrospective nature of the analysis, the lack of a control group with nonembolized tumors, and the aforementioned bias toward the use of Gelfoam in detriment of other embolic agents.

\section{Conclusion}

Glomus jugulare tumors are complex lesions that demand a multidisciplinary approach to ensure satisfactory resection with preservation of lower cranial nerves, especially in case of intracranial extension. Preoperative embolization is essential to ensure one-stage operation of such hypervascularized lesions; there is a wide variety of techniques and material available for the interventional neuroradiologist. Complications from embolization, though rare, cannot be overlooked.

\section{Authors Contributions}

Pedro MKF: manuscript research and composition

Leal AG: manuscript research and composition

Ramina R: manuscript revision

Meneses MS: manuscript revision

\section{Conflict of Interests}

The authors have no conflict of interests to declare.

\section{References}

1 Harati A, Deitmer T, Rohde S, Ranft A, Weber W, Schultheiß R Microsurgical treatment of large and giant tympanojugular paragangliomas. Surg Neurol Int 2014;5:e179

2 Al-Mefty O, Teixeira A. Complex tumors of the glomus jugulare: criteria, treatment, and outcome. J Neurosurg 2002;97(06): 1356-1366

3 Boedeker CC, Ridder GJ, Schipper J. Paragangliomas of the head and neck: diagnosis and treatment. Fam Cancer 2005;4(01): 55-59

4 Bitaraf MA, Alikhani M, Tahsili-Fahadan P, et al. Radiosurgery for glomus jugulare tumors: experience treating 16 patients in Iran. J Neurosurg 2006;105 (Suppl):168-174

5 de Andrade EM, Brito JR, Mario SD, de Melo SM, Benabou S. Stereotactic radiosurgery for the treatment of Glomus Jugulare Tumors. Surg Neurol Int 2013;4(Suppl 6):S429-S435
6 Genç A, Bicer A, Abacioglu U, Peker S, Pamir MN, Kilic T. Gamma knife radiosurgery for the treatment of glomus jugulare tumors. J Neurooncol 2010;97(01):101-108

7 Gerosa M, Visca A, Rizzo P, Foroni R, Nicolato A, Bricolo A. Glomus jugulare tumors: the option of gamma knife radiosurgery. Neurosurgery 2006;59(03):561-569, discussion 561-569

8 Liu JK, Sameshima T, Gottfried ON, Couldwell WT, Fukushima T. The combined transmastoid retro- and infralabyrinthine transjugular transcondylar transtubercular high cervical approach for resection of glomus jugulare tumors. Neurosurgery 2006;59(01, Suppl 1):ONS115-ONS125, discussion ONS115-ONS125

9 Sanna M, Shin SH, De Donato G, et al. Management of complex tympanojugular paragangliomas including endovascular intervention. Laryngoscope 2011;121(07):1372-1382

10 Ramina R, Maniglia JJ, Fernandes YB, Paschoal JR, Pfeilsticker LN, Coelho Neto M. Tumors of the jugular foramen: diagnosis and management. Neurosurgery 2005;57(01):59-68, discussion 59-68

11 Griauzde J, Srinivasan A. Imaging of vascular lesions of the head and neck. Radiol Clin North Am 2015;53(01):197-213

12 Phelps PD, Stansbie JM. Glomus jugulare or tympanicum? The role of CT and MR imaging with gadolinium DTPA. J Laryngol Otol 1988;102(09):766-776

13 Makiese O, Chibbaro S, Marsella M, Tran Ba Huy P, George B. Jugular foramen paragangliomas: management, outcome and avoidance of complications in a series of 75 cases. Neurosurg Rev 2012;35(02):185-194, discussion 194

14 Wilson MA, Hillman TA, Wiggins RH, Shelton C. Jugular foramen schwannomas: diagnosis, management, and outcomes. Laryngoscope 2005;115(08):1486-1492

15 George B. Jugulare foramen paragangliomas. Acta Neurochir (Wien) 1992;118(1-2):20-26

16 Christie A, Teasdale E. A comparative review of multidetector CT angiography and MRI in the diagnosis of jugular foramen lesions. Clin Radiol 2010;65(03):213-217

17 Dawbarn R. The starvation operation for malignancy in the external carotid area. J Am Med Assoc 1904;(13):792-795

18 Brooks B. The Treatment of Traumatic Arteriovenous Fistula. Southern Medical Journal South Med J 1930;23(02):100-106

19 Moniz E. Les injections carotidiennes et les substances opaques. Presse Med 1926;63:969-971

20 Moniz E. L'encéphalographie artérielle, son importance dans la localisation des tumeurs cérébrales. Rev Neurol (Paris) 1927; 2:72-90

21 Seldinger SI. Catheter replacement of the needle in percutaneous arteriography; a new technique. Acta Radiol 1953;39(05):368-376

22 Djindjian R, Merland JJ, Rey A, Thurel J, Houdart R. [Superselective arteriography of the external carotid artery. Importance of this new technic in neurological diagnosis and in embolization]. Neurochirurgie 1973; **:165-171

23 Hekster RE, Luyendijk W, Matricali B. Transfemoral catheter embolization: a method of treatment of glomus jugulare tumors. Neuroradiology 1973;5(04):208-214

24 Hilal SK, Michelsen JW. Therapeutic percutaneous embolization for extra-axial vascular lesions of the head, neck, and spine. J Neurosurg 1975;43(03):275-287

25 Schick PM, Hieshima GB, White RA, et al. Arterial catheter embolization followed by surgery for large chemodectoma. Surgery 1980;87(04):459-464

26 George B, Casasco A, Deffrennes D, Houdart E. Intratumoral embolization of intracranial and extracranial tumors: technical note. Neurosurgery 1994;35(04):771-773, discussion 773-774

27 Jacobs JM, Shelton C, Thompson BG. Combined transarterial and transvenous embolisation of jugulotympanic paragangliomas. Interv Neuroradiol 1998;4(03):223-230

28 Moret J, Delvert JC, Bretonneau CH, Lasjaunias P, de Bicêtre $\mathrm{CH}$. Vascularization of the ear: normal-variations-glomus tumors. J Neuroradiol 1982;9(03):209-260 
29 White JB, Link MJ, Cloft HJ. Endovascular embolization of paragangliomas: A safe adjuvant to treatment. J Vasc Interv Neurol 2008;1(02):37-41

30 Kocur D, Ślusarczyk W, Przybyłko N, et al. Endovascular Approach to Glomus Jugulare Tumors. Pol J Radiol 2017;82:322-326

31 Murphy TP, Brackmann DE. Effects of preoperative embolization on glomus jugulare tumors. Laryngoscope 1989;99(12): 1244-1247

32 Patel SJ, Sekhar LN, Cass SP, Hirsch BE. Combined approaches for resection of extensive glomus jugulare tumors. A review of 12 cases. J Neurosurg 1994;80(06):1026-1038

33 Dalfino JC, Drazin D, Nair A, Gifford E, Boulos AS. Successful Onyx embolization of a giant glomus jugulare: case report and review of nonsurgical treatment options. World Neurosurg 2014;81(56):842.e11-842.e16

34 Young NM, Wiet RJ, Russell EJ, Monsell EM. Superselective embolization of glomus jugulare tumors. Ann Otol Rhinol Laryngol 1988;97(6 Pt 1):613-620

35 Gonda DDTJ, Wong WH, Nguyen AD. Preoperative Onyx Embolization of Glomus Jugulare Tumor Complicated by Surgical Displacement of Embolic Material: Case Report. J Neurol Disord 2015;3(01):207

36 Gaynor BG, Elhammady MS, Jethanamest D, Angeli SI, Aziz-Sultan MA. Incidence of cranial nerve palsy after preoperative emboli- zation of glomus jugulare tumors using Onyx. J Neurosurg 2014; 120(02):377-381

37 Ozyer U, Harman A, Yildirim E, Aytekin C, Akay TH, Boyvat F. Devascularization of head and neck paragangliomas by direct percutaneous embolization. Cardiovasc Intervent Radiol 2010;33 (05):967-975

38 Tasar M, Yetiser S. Glomus tumors: therapeutic role of selective embolization. J Craniofac Surg 2004;15(03):497-505

39 Harris S, Brismar J, Cronqvist S. Pulsatile tinnitus and therapeutic embolization. Acta Otolaryngol 1979;88(3-4):220-226

40 Michelozzi C, Januel AC, Cuvinciuc V, et al. Arterial embolization with Onyx of head and neck paragangliomas. J Neurointerv Surg 2016;8(06):626-635

41 Sanna M, Piazza P, De Donato G, Menozzi R, Falcioni M. Combined endovascular-surgical management of the internal carotid artery in complex tympanojugular paragangliomas. Skull Base 2009;19 (01):26-42

42 Sanna M, Piazza P, Ditrapani G, Agarwal M. Management of the internal carotid artery in tumors of the lateral skull base: preoperative permanent balloon occlusion without reconstruction. Otol Neurotol 2004;25(06):998-1005

43 Piérot L, Boulin A, Castaings L, Chabolle F, Moret J. [Embolization by direct puncture of hypervascularized ORL tumors]. Ann Otolaryngol Chir Cervicofac 1994;111(07):403-409 